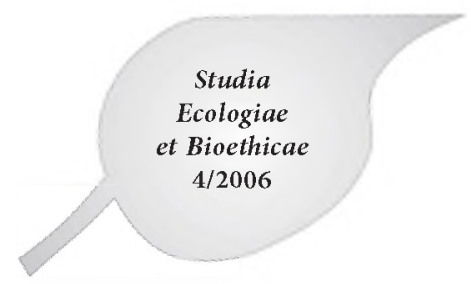

\title{
Analiza stylistyczno-porównawcza karpackich obiektów sakralnych ze szczególnym uwzględnieniem greckokatolickiej świątyni w Łosiu $^{1}$
}

Podjęcie problemu analizy stylistyczno-porównawczej obiektów cerkiewnych zakłada poczynienie wstępnych uwag odnośnie charakteru karpackich świątyń. Kłopoty związane $\mathrm{z}$ opisem wschodniochrześcijańskiej architektury sakralnej w Karpatach pojawiają się już w momencie próby ustalenia jej genezy. Chociaż debata na ten temat toczy się nie od dzisiaj, to w zasadzie większość badaczy nie ma wątpliwości, że formuły i zasady techniki budowlanej świątyń wschodniego chrześcijaństwa w Karpatach wypracowane zostały jeszcze w erze przedchrześcijańskiej (tj. przed przyjęciem chrześcijaństwa przez Ruś w 988 r.). Spostrzeżenie to opiera się na podobieństwie istniejącym między charakterem budownictwa sakralnego i wcześniej wznoszonych budynków mieszkalnych, idealnie przystosowanych do osobliwości przyrodniczych górskiego regionu. Charakteryzując chaty wschodnich sąsiadów Łemków - Bojków, ukraiński badacz budownictwa , Krawczenko, pisze: „Ludowi mistrzowie ciesielscy dokładnie rozumieli przyrodę i szukali z nią harmonii. Chaty zbudowane $\mathrm{z}$ grubych belek, $\mathrm{z}$ wysokimi łukowatymi dachami, przypominają z daleka stare jodły z opuszczonymi gałęziami (...) Oryginalny zewnętrzny wygląd takiej chacie nadaje wysoki dach, szeroka galeria wzdłuż budynku, przykrycie podtrzymywane artystycznie rzeźbionymi słupami, niewielkie okna oraz masywne drzwi z ornamentalnie rzeźbionymi odrzwiami"(ukr.) $)^{2}$. Także znany arabski podróżnik Ibn-Dast relacjonował w kronice, że Słowianie przykrywali chaty drewnianymi, ostrymi dachami, które później pojawiły się na ich chrześcijańskich świątyniach ${ }^{3}$. Wołodymyr Siczynśkij rozpatrując genezę cerkwi ruskich umiejscawia ich najbardziej archaiczny typ

Niniejszy opis greckokatolickiego obiektu w Łosiu bazuje na analizie pomiarów brył oraz ocenie polichromii wnętrza cerkwi dokonanej przez autorkę tekstu.

2 J.O. Krawczenko, Tradycji derewianoji monumentalnoji architektury Karpat, w: Narodnja tworczist' ta etnohrafija, 1986, Nr 3, s. 55. 
na Bojkowszczyźnie (orientacyjnie Bieszczady) - karpackiej krainie położonej na wschód od regionu Łemków (orientacyjnie Beskid Niski). Dalsze analizy doprowadzily go do przekonania, ze młodsze lemkowskie budownictwo cerkiewne ukształtowało się pod wpływem starszej architektury bojkowskiej. Nieco odmienne spojrzenie na genezę lemkowskiej architektury sakralnej zaproponował Ryszard Brykowski głosząc tezę przeczącą twierdzeniu Siczyńskiego, że bojkowskie cerkwie stanowią formę pierwotną. Punktem wyjścia rozumowania Brykowskiego było przekonanie, że formami starszymi są budowle rozrzucone w sposób wyspowy na szerszej przestrzeni. Ponieważ cerkiewki bojkowskie, w przeciwieństwie do łemkowskich, zajmują stosunkowo niewielkie, ale za to zwarte terytorium, mogą stanowić formę późniejszą. Wynikałby z tego prosty wniosek o wzorowaniu się młodszych architektonicznie świątyń Bojków na budownictwie łemkowskim. Brykowski formułuje swe spostrzeżenia niezwykle ostrożnie i można odnieść wrażenie, że w tym wypadku chodzi bardziej o hipotezę, niż ostateczny wniosek ${ }^{4}$.

Abstrahując od genezy i chronologii form architektonicznych w regionie karpackim należy podkreślić, że kwestią oczywistą była dyfuzja elementów architektonicznych na omawianych pograniczach kulturowych, w których krzyżowały się wpływy cywilizacyjne zarówno Wschodu, jak i Zachodu. Do wschodnich wzorców zaliczyć można trójzrębowe i trzywieżowe rozwiązania, do zachodnich natomiast konstrukcję wysokich wież $\dot{z}^{5}$. Tadeusz Chrzanowski podkreśla, że łemkowska architektura sakralna przejęła $\mathrm{z}$ konstrukcji wieży zachodniej formę baniastego hełmu z latarnią, który wraz ze wzbogaceniem przykrycia wielokrotnie łamanym dachem i wysubtelnieniem sylwety obiektu, dostosowany został do form wschodniej architektury sakralnej ${ }^{6}$. Latynizacja budownictwa cerkiewnego była ułatwiona poprzez bezpośredni kontakt z drewnianymi kościółkami małopolskimi. Łącząc w sobie budownictwo małopolskie z ruską architekturą sakralną, cerkwie mieszkańców Karpat, stały się ogniwem pośrednim między łacińskim gotykiem, a cerkwiami wschodnimi Ukrainy ${ }^{7}$.

3 Por. W. Karmazyn-Kakowśkij, Mystectwo temkiwśkoji cerkwy, Rzym 1975, s. 12.

4 R. BRYKowski, Łemkowska architektura cerkiewna w Polsce, na Stowacji i Rusi Zakarpackiej, Wrocław 1986, s. 69-70.

5 Trójzrębowe i trzywieżowe rozwiązania można znaleźć już wśród miniatur „Izbornika Welykoho Kaniazia Światosława 1072” oraz kijowskiego „Psałtyra” z XI wieku. Por:: W. SIczY nśkIJ, Istorija ukrajinśkoho mystectwa, w: Architektura, T. 1., Nowy Jork 1956, s. 103-109.

6 T. Chrzanowski, K. Piwocki, Drewno w polskiej architekturze i rzeźbie ludowej, Wrocław i in., 1981, s. 12.

7 Ks. Z. Bielamowicz, Świadectwa wzajemnych oddzialywań obrządku lacińskiego i bizantyńskiego w sztuce sakralnej na ziemiach polskich w epoce baroku, w: Polska-Ukraina. 1000 lat sąsiedztwa, T2, Przemyśl 1994, s. 374. 
Do latynizacji sztuki cerkiewnej przyczyniła się szczególnie unia brzeska, w trakcie której część biskupów ruskiej Cerkwi prawosławnej uznała prymat papieża i utrzymując dotychczasowy wschodni obrządek, przyjęła dogmatykę Kościoła rzymskokatolickiego (1596). Nowe przepisy dotyczące nabożeństw i wystroju cerkiewnego skodyfikowano dopiero w 1720 roku na ważnym dla tradycji Cerkwi unickiej (greckokatolickiej) synodzie zamojskim, którego przełomowe znaczenie przyrównywane jest do znaczenia Soboru Trydenckiego dla dziejów Kościoła łacińskiego. Jednym ze skutków synodu stała się latynizacja architektury i wystroju cerkiewnego: dekompletowano ikonostasy, wprowadzano wysokie nastawy przy ołtarzu głównym i ołtarze boczne o charakterze łacińskich barokowych nastaw, często wielokondygnacyjnych, a także pełnoplastyczne postaci świętych lub aniołów oraz ambony i chóry muzyczne. W niektórych regionach, zwłaszcza na Chełmszczyźnie, pojawiły się nawet organy, nigdy wcześniej nie spotykane w tradycji liturgicznej Kościoła Wschodniego. Poważną rolę w okcydentalizacji sztuki cerkiewnej odegrał barok, którego silny wplyw nie zmienił jednak układu przestrzennego poszczególnych brył budynku cerkiewnego. Oddziaływanie barokowych wzorców dotyczyło bardziej detali architektonicznych i sztuki zdobniczej, niż układu przestrzennego, co wynikało z tradycji Kościoła Wschodniego, zgodnie z którą niezmienność i trwałość idei boskich znajdowało swe odzwierciedlenie w stałości form architektonicznych ${ }^{8}$.

Wraz z przyłączeniem Galicji, w tym też regionu karpackiego, do monarchii habsburskiej (1772), pojawily się nowe tendencje $w$ drewnianej architekturze sakralnej, a wnętrza cerkiewne zaczęto przekształcać zgodnie z nowoczesnymi ideami artystycznymi. Zgodnie z oceną Zofii Szanter nowe budowle sakralne charakteryzowały się: 1) większymi rozmiarami obiektu oraz dużymi symetrycznie umieszczonymi oknami rozświetlającymi wnętrze cerkwi; 2) rozszerzoną nawą, tworzącą $\mathrm{z}$ babińcem jedno wnętrze z zatraceniem tradycyjnego trójpodziału; 3) polichromiami figuralnymi przedstawiającymi najczęściej Ducha świętego lub Trójcę Świętą w sanktuarium, natomiast w nawie Św. Trójcę, Przemienienie lub sceny z życia Chrystusa, a także popiersia czterech Ewangelistów, i w końcu w przednawie Matkę Bożą typu Pokrowa, Zwiastowanie, Marię Orantkę lub Michała Anioła9.

Obraz karpackiej architektury sakralnej jest bardzo zróżnicowany pod względem przestrzennego formowania bryły. Jakkolwiek potrzebę klasyfikacji

\footnotetext{
8 Wpływ baroku na ruską architekturę i sztukę sakralną był tak olbrzymi, że nadano mu miano „baroku ukraińskiego” lub „baroku kozackiego”. Por. W. SiczyńsKiJ, Drewne stawby w Karpatske oblasti, Praga 1940, s. 114.

9 Z. Szanter, Wystrój wnętrza cerkwi w Beskidzie Niskim i Sądeckim, w: Lemkowie. KulturaSztuka-Język. Materiaty z sympozjum zorganizowanego przez Komisję Turystyki Górskiej ZG PTTK, Sanok dn. 21-24 września 1983. Warszawa-Kraków 1987, s. 74-75.
} 
budowli sygnalizowali już inni badacze architektury, to jednak praca Ryszarda Brykowskiego przynosi pewne trwałe rozwiązanie. Badacz wyróżnił pięć typów świątyń karpackich, w zależności od czasu powstania i obszaru występowania oraz ze względu na specyfikę architektoniczną obiektów:

- typ północno-zachodni - tworzy go 70 cerkwi w zachodnim i środkowym obszarze łemkowskim po polskiej stronie, oraz po stronie Słowackiej. Wariant starszy charakteryzuje się rzutem trójdzielnym z szerszą nawą, zróżnicowaną wysokością trzech członów oraz wieżą izbicową, natomiast wariant młodszy rozpoznać można po powszechności występowania zakrystii i częstym stosowaniem trójbocznego zamknięcia,

- typ południowy - obejmuje słowacką stronę Karpat, tworzy je zbiór sześciu świątyń. Od poprzedniego różnią się przede wszystkim częstym występowaniem rzutu dwudzielnego (obok trójdzielnego),

- typ południowo-wschodni - obejmuje sześć obiektów zachodniego obszaru Rusi Zakarpackiej, których kopuły posiadają wiele załamań oraz szerokie podcienie otaczające część wieżową i nawę,

- typ północno-wschodni - składa się z dwunastu obiektów wschodniego obszaru łemkowskiego po polskiej stronie Karpat, wśród których spotkać można wariant wieżowy i bezwieżowy. Obok cerkwi, na jej osi podłużnej, sytuuje się wolno stojąca dzwonnica,

- typ północno-schylkowy - obejmuje zachodni i środkowy obszar łemkowski na północnym stoku Karpat. Składa się z dwunastu świątyń, charakteryzujących się trój-i dwudzielnymi rzutami, trójbocznie zamkniętym sanktuarium (najczęściej z zakrystią), wieżami o ścianach pochyłych zwieńczonych izbicami, brakiem łamanych dachów zastąpionych przez dachy dwuspadowe oraz wnętrzami krytymi stropem płaskim ${ }^{10}$.

Chociaż przedstawiona wyżej typologia nie rozwiązuje w zupełności problemu klasyfikacji drewnianych obiektów sakralnych wschodniego chrześcijaństwa w Karpatach i nie wszystkie budowle dadzą ująć się w schematy omawianych typów, to z pewnością propozycja Ryszarda Brykowskiego jest pomocna w usytuowaniu greckokatolickiej świątyni w Łosiu pośród innych obiektów oraz umożliwia przeprowadzenie analizy stylistyczno-porównawczej w ramach jednego typu - północno-schyłkowego, do którego należy ta cerkiew.

Greckokatolicka świątynia pod wezwaniem Najświętszej Marii Panny w Łosiu $^{11}$ wzniesiona została w 1810 roku i jest zbudowana, podobnie jak większość

${ }_{10}$ Więcej na temat klasyfikacji obiektów cerkiewnych por.: R. BRyкowsкi, Lemkowska architektura..., op.cit., Wroclaw 1986.

11 Miejscowość Łosie została pierwotnie lokowana w 1359 roku, ponownie zaś w 1524 roku na prawie wołoskim. Na początku XX wieku zasłynęła $\mathrm{z}$ handlu mazią produkowaną z miejscowej ropy naftowej. Szlaki podróży maziarskich sięgały odległych miast Austro-Węgier, Kongresówki i Rosji, a handel zapewnial mieszkańcom wysoki standard życia i decydował o wyjątkowości 
obiektów tego typu, na tradycyjnym rzucie trójdzielnym, składającym się z trzech pomieszczeń: sanktuarium, nawy i babińca rozmieszczonych na osi wschód-zachód ${ }^{12}$. W związku z tym, że podczas przebudowy cerkwi w 1928 roku poszerzono nawę, całość układu nabrała cech planu krzyżowego wzbogaconego o dwie prostokątne przybudówki zakrystyjne dołączone od północy i południa do prezbiterium. W obrębie typu północno-schyłkowego nie występują obiekty posiadające dwie zakrystie. Częściej spotykana jest tylko jedna, usytuowana od strony północnej lub, jak w Ropicy Ruskiej, południowej. Rozwiązanie takie naruszało idealną symetrię planu, co kłóciło się z założeniami liturgicznymi obrządku wschodniego i skłaniało do zastosowania nowej reguły architektonicznej: zakrystię zaczęto wyodrębniać ze wschodniej części prezbiterium. Ten typ planu występuje w cerkwiach Nowicy, Zdyni i Żółkiewce. Część kapłańska, mniejsza od nawy, zamknięta bywa najczęściej trójbocznie. Od schematu tego odbiegają cerkwie w Królowej Ruskiej o prezbiterium dwubocznym oraz w Łosiu, gdzie prezbiterium zostało zamknięte ścianą prostą. Zamknięcie takie jest formą pierwotniejszą oraz powszechniejszą, podczas gdy wieloboczne sanktuaria zaczęly pojawiać się dopiero od końca XVIII wieku, by na początku XIX stulecia stać się niemalże regułą.

Analizując bryłę cerkwi łemkowskich należy uwzględnić charakter babińca, z którym pośrednio wiąże się wielość rozwiązań konstrukcyjnych wieży. Wśród cerkwi typu północno-schyłkowego dominuje reguła, zgodnie z którą słupy nośne wieży ujmują babiniec. Pewnymi wyjątkami w tej prawidłowości są świątynie w Dolinach, Banicy i Łosiu. W pierwszej z nich słupy nośne obejmują babiniec od strony zachodniej, podczas gdy od strony wschodniej wbudowane zostały w nawę, w drugim przypadku usytuowano je w przedłużeniu nawy, w cerkwi łosiańskiej zaś wieża została umiejscowiona w przedłużeniu babińca oraz jest od niego nieco szersza, przez co cały przedsionek z częścią babińca ukryty został w dolnej części wieży. Stałą regułą była również zasada pochyłości ścian wieży (proste niemal ściany występowały jedynie w cerkwi doliniańskiej) zaopatrzonej w izbicę zwieńczoną baniastymi, barokowymi hełmami ${ }^{13}$. Bogato zdobione pomieszczenie izbicowe (pseudizbicowe - Nowica, Przysłup, Ropica Ruska, Wawrzka, Zdynia, Żydowskie) stanowily fragment budowli dającej artyście bu-

wsi. Por. M. Brylak-ZaŁuska, Maziarska wieś Losie, Kraków 1983; W. Piatkowski, Maziarze, w: Magury 1986, s. 3-8.

12 Spośród tej klasy budowli tylko cerkiew w Banicy orientowana jest na południe, a plan dwudzielny będący skutkiem wpływów zachodniej architektury kościelnej można spotkać w cerkwiach w Królowej Ruskiej, Polanach, Dolinach i Żydowskiem.

13 Izbice, jako najwyższe, nadwieszone kondygnacje $w$ drewnianych wieżach, są nieodłącznym atrybutem zabytków starszych (XVII-połowa XVIII wieku), pdeudoizbice występują natomiast w budowlach młodszych. 
downiczemu możliwość prezentacji własnego smaku artystycznego. Najczęściej spotykanym zabiegiem dekoracyjnym było ozdabianie ścianek izbicy pionowymi listwami w kształcie arkadek (Nowica) lub dzielenie ich poziomą listwą - gzymsem na dwie kondygnacje. Inny element ozdobny stanowily usytuowane wzdłuż dolnej i górnej krawędzi izbicy dekoracyjnie profilowane gzymsy, rozpowszechnione w epoce baroku. Spotkać je można na przykład w cerkwiach Królowej Ruskiej, Boguszy, czy Banicy. Z okresem kultury barokowej wiąże się również zdobienie izbic pozornymi tarczami zegarowymi z obiegającym je wyłamanym półkoliście gzymsem (Banica, Bogusza) ${ }^{14}$.

Wieża cerkwi w Łosiu zwieńczona została izbicą nie różniącą się w swym zarysie konstrukcyjnym od izbic innych cerkwi, jednak elementy dekoracyjne ograniczone zostały do minimum. Jedyną jej ozdobę stanowi podłużna, prosta listwa obiegająca dolną krawędź izbicy oraz półkoliście wycięte otwory okienne w ilości po dwa z każdej strony. Technika wznoszenia budynku cerkiewnego w omawianym typie charakteryzuje się nie zawsze zróżnicowaną wysokością zrębu poszczególnych członów. Jednakowa wysokość całego zrębu występuje w trzech cerkwiach: Królowej Ruskiej, Ropicy Ruskiej i Łosiu. Cerkiew łosiańska wzniesiona została w konstrukcji zrębowej z bierwion o przekroju prostokątnym zwęgłowanym na powszechnie stosowany prosty zamek. W przeciwieństwie do zasady stałości ujęcia rzutu poziomego, konstrukcja partii dachowych drewnianych świątyń karpackich mogła być bardziej dowolna. Formy dachowe zależały do możliwości materialnych ludności, chęci kontynuacji tradycji, a także umiejętności ciesielskich budowniczych. Powszechnie stosowanym nakryciem świątyń typu północno-schyłkowego są dachy dwuspadowe, niższe nad prezbiterium, zakończone przeważnie pół stożkowo lub wielopołaciowo. Od reguły tej odbiega jedynie świątynia w Królowej Ruskiej, charakteryzująca się dachem kalenicowym wspólnym dla nawy i sanktuarium.

$\mathrm{Na}$ skutek często podejmowanej praktyki modernizacji budynki cerkiewne omawianego typu utraciły swe zrębowe kopuły, a ich miejsce zajęły różnorodne formy sterczyn. Dlatego też poszczególne człony cerkwi w Łosiu zwieńczone zostały charakterystycznymi wieżyczkami sygnaturkowymi z pozornymi latarniami nad trzema hełmami. Od schematu powyższego odbiega na przykład cerkiew w Polanach, nie posiadająca latarni nad prezbiterium oraz świątynia w Zdyni zwieńczona wysokimi czterokondygnacyjnymi (nad nawą) i trójkondygnacyjnymi (nad prezbiterium) wieżyczkami sygnaturkowymi.

14 Forma ta zapożyczona została $z$ murowanych barokowych wież, występujących od połowy XVIII wieku aż po epokę józefińską do połowy XIX wieku. Por. M. Kornecri, Sztuka Kresu Muszyńskiego, maszynopis, s. 37. 
Jak wcześniej wspomniano dominującą cechą omawianych cerkwi jest ich trójdzielność, której konsekwencją jest wewnętrzny trójczłonowy podział: sanktuarium, nawa i babiniec. Trójczłonowość cerkwi wpisała się tak mocno w tradycję, że nawet zmiana funkcji babińca, przeznaczonego pierwotnie wyłącznie dla kobiet, nie zachwiała zasadami konstrukcyjnymi budowli.

Świątynia w Łosiu nie posiada ściany oddzielającej babiniec od nawy, a granicę pomiędzy tymi bryłami podkreśla jedynie większa szerokość nawy. Babiniec został oddzielony od kruchty ścianą z dużymi, ciężkimi drzwiami, a nawę od sanktuarium (prezbiterium) oddziela usytuowany na linii styku tych pomieszczeń ikonostas ${ }^{15}$. Odrębność poszczególnych członów została zasygnalizowana dodatkowo różną wysokością brył oraz zróżnicowanym poziomem podłogi podwyższonej nieco w sanktuarium. Taki sposób wyróżnienia prezbiterium od części wiernych charakterystyczny jest dla większości cerkwi łemkowskich ${ }^{16}$.

Kilka uwag należy poświęcić malarstwu ściennemu, którego analiza przekonuje o zgodności motywów polichromicznych z ogólnie przyjętymi wzorcami propagowanymi przez austriacki rząd Habsburgów. I tak na przykład w cerkwi łosiańskiej na stropie nawy umieszczono wizerunek Zmartwychwstałego, na wpół obnażonego Chrystusa z Bogiem Ojcem na tle błękitnej przestrzeni niebiańskiej, globem ziemskim pod stopami oraz gołębicą ${ }^{17}$. W narożnikach sceny usytuowane zostały wizerunki czterech Ewangelistów wraz z atrybutami. Wyzej omówione sceny malarstwa ściennego spotykane są nie tylko w obrębie omawianego północno-schyłkowego typu (Nowica, Łosie), ale także poza nim (Dudyńce 1802; Rudenka-1843; Sanoczek -1870) ${ }^{18}$.

15 Umieszczanie zespołu ikon na przegrodzie pomiędzy nawą, w której modlą się wierni, a przestrzenią apsydową, gdzie kapłani i diakoni odprawiają liturgię, jest charakterystyczne dla świątyń chrześcijańskich na wschodzie. Taki podział wnętrza widoczny był już w X-XI stuleciu w świątyniach bizantyńskich. Najszerszy program ikonograficzny spotykany był w księstwach ruskich, w których ikonostas rozbudowany został do rozmiarów wielokondygnacyjnej ściany utworzonej przez ogromne ikony, uporządkowane w kilka rzędów. Por. O. Popova, Engelina Smimova, Paola Cortesi, Ikony, Warszawa 1998, s. 12.

16 Inne rozwiązanie polega na obniżeniu poziomu podłogi w nawie przy równoczesnym zachowaniu wyższych poziomów w sanktuarium i babińcu.

17 Golębica - ptak najczęściej pojawiający się na kartach Biblii: w Księdze Rodzaju był znakiem pokoju Bożego nadchodzącego po klęsce potopu, w „Pieśni nad Pieśniami” oznaczał nieskalane piękno (podobnie jak u starożytnych). W Nowym Testamencie jest zwiastunem Bożego przesłania, a także ikonograficznym wizerunkiem Ducha Świętego. Golębicę spotykamy także przy wyobrażeniach Zwiastowania Marii w polichromii babińca w cerkwi łosiańskiej.

18 Istnieje przekonanie, że wzniesienie licznych cerkwi greckokatolickich w XIX wieku oraz wykonanie standardowej polichromii odbywało się w kontekście szerokiej akcji przygotowywań Cerkwi greckokatolickiej do uroczystych obchodów 950-lecia Chrztu Rusi Kijowskiej. 
Przechodząc do detali architektonicznych na pierwszym miejscu należałoby zająć się kwestią otworów okiennych i drzwiowych. Okna o zróżnicowanej wielkości wypełnione kolorowymi szybkami, spełniającymi funkcję praktyczną i estetyczną, zostały zabezpieczone żelaznymi kratami okiennymi, których genezę wywodzi się w prostej linii od krat średniowiecznych. Omawiając szczegóły architektoniczne cerkwi nie sposób przemilczeć kutych krzyży wieńczących hełmy wież i wieżyczek sygnaturkowych, które swą tradycją sięgają co najmniej XVIII wieku. Wykonywano je z kutego płaskownika lub pręta łączonego techniką nitowania lub zgrzewania ${ }^{19}$. W przypadku próby klasyfikacji krzyży kutych istnieją ogromne trudności, co wiąże się z niezwykłą różnorodnością form i niepowtarzalną ornamentalną dekoracyjnością. Każdy z krzyży, mimo że wykonany z podobnych form i elementów, posiada oryginalny, sobie tylko właściwy, szkic. W omawianym północno-schyłkowym typie oprócz krzyży odznaczających się wyjątkową dekoracyjnością (Bogusza, Nowica, Łosie), spotyka się krzyże skromniejsze o nieskomplikowanych formach (Banica, Doliny, Królowa Ruska). Mocno profilowane i dekorowane krzyże zwykło się nazywać „kwitnącymi” lub „krzyżami na krzyżach”. Główny element konstrukcyjny kutego z żelaza krzyża, wieńczącego wieżyczki cerkwi w Łosiu, stanowi skrzyżowanie ramion podkreślone profilowanym kółkiem, wyposażonym dodatkowo w cztery małe krzyże. Podobne okręgi wieńczą wszystkie cztery ramiona, przy czym umieszczono na nich jeszcze większą ilość krzyży (sześć na pionowym ramieniu i siedem na kółkach poziomego ramienia). U nasady krzyża znajduje się półksiężyc, co symbolizuje zwycięstwo chrześcijaństwa nad pogaństwem.

Podjętą analizę należy dopełnić informacjami dotyczącymi zewnętrznego wykończenia świątyni, która wykonana z drewna pokryta była, zgodnie z przyjętą regułą, gontem. Jednak w momencie pojawienia się nowoczesnych tendencji architektonicznych, najprawdopodobniej w 1928 roku, ściany budowli pokryto tynkiem. W 1983 roku nastąpił powrót do tradycji i bryła świątyni została ponownie oszalowana, dzięki czemu cerkiew odzyskała powszechnie spotykany w Karpatach charakter cerkiewki obitej poziomym gontem nadkładkowym.

Otoczenie nie wyróżniało się niczym szczególnym od innych świątyń typu północno-schyłkowego. Typ kamiennego muru przykrytego daszkiem gontowym (Zdynia, Łosie) bądź nie (Banica) jest powszechnie spotykany w regionie. Wyjątek stanowi ogrodzenie świątyni w Przysłopiu, które wykonano z drewnianych, poziomo ułożonych belek. Do otoczenia świątyni należy także dzwonnica i bramka wejściowa. Najczęściej wznoszono je $z$ drewna. Genezę dzwonnic cerkiewnych, z których najstarsze datowane są na XVI-XVII wiek, wywodzi się z zamkowo-obronnego budownictwa. Dzwonnice wznoszono na planie kwadratu, $\mathrm{z}$ fartuchem $\mathrm{w}$ dolnej części, oraz oknami wyciętymi w ilości od jednego do

19 R. ReInfuss, Ludowe kowalstwo artystyczne w Polsce, Wrocław i in. 1983, s. 95. 
sześciu z każdej strony w części górnej ${ }^{20}$. Łosiańska dzwonnica i bramka nie są drewniane, lecz murowane, co znajduje wyjaśnienie w ich późniejszej dobudowie, już w erze józefińskiej. Obie umieszczone są w ogrodzeniu okalającym plac cerkiewny. Bramkę wieńczy daszek namiotowy, przechodzący w ośmiopalowy hełm baniasty ze ślepą latarnią i makówką, na której usytuowano żelazny krzyż. Na górnej części ścian pod okapem umieszczono daty upamiętniające chrzest Polski (od strony zachodniej) i Rusi (od strony wschodniej). Na sklepieniu umieszczono Herb Papieski z datami wizyt Jana Pawła II w Polsce.

Parawanowa dzwonnica, wzniesiona na planie wydłużonego prostokąta, jest dwukondygnacyjna: dolną część tworzy otwór wejściowy w kształcie łuku, górna kondygnacja natomiast przepruta została trzema otworami, zamkniętymi półkoliście, w których powieszono dzwony: Marię, Józefa i Wolodymyra. Mimo tego, że dzwonnica i bramka, w przeciwieństwie do obitej gontami cerkwi, są murowane i otynkowane, tworzą one ze świątynią harmonijną całość, którą osiągnięto dzięki jednolitości baniastych wież i pokrewnemu charakterowi brył przestrzennych.

Świątynia w Łosiu wpisuje się wspaniale w urokliwy krajobraz górski. Usytuowana w widłach rzeki Ropy i wpadającego do niej potoku, wzniesiona na tle góry Kiczery i otoczona wieńcem rosłych drzew, zlewa się z otaczającą ją rzeczywistością w harmonijną jedność. Rzeczą najistotniejszą jednak jest to, że oddycha ona powietrzem swego naturalnego bytu artystycznego i nie podzieliła losu innych obiektów sztuki przeniesionych do muzeów i skansenów, w których, jak pisze Paweł Florenski, „dokonuje się zamiana skończonego pod względem artystycznym malowidła na jego szkic, często dodatkowo zniekształcony". Poruszając problem umieszczania zabytkowych obiektów w skansenach ten znakomity znawca sakralnej sztuki wschodniej stawia, zdaje się, retoryczne pytanie: „Cóz powiedzielibyśmy o ornitologu, który zamiast zajmować się obserwacją życia ptaków poświęcitby się wylącznie kolekcjonowaniu pięknie wypchanych okazów?”21.

\title{
A stylistic comparison of Carpathian religious objects particularly with regard to the Greco-Catholic Church in Łosiu
}

\author{
SUMMARY
}

The article contains a stylistic comparison of the analysis of religious objects and their description of the landscape of the Carpathian region. Summary to SEB.

\footnotetext{
20 Prócz kwadratowych dzwonnic znany jest także typ dzwonnicy ośmiobocznej, ale występuje on jedynie na Bukowinie i Huculszczyźnie Por. W.SICZY NSKIJ, Ukrajinskie derewjane budiwnyctwo i rizba, Lwów 1936, s. 20.

21 P. FloRenski, Ikonostas $i$ inne szkice, Warszawa 1984, s. 45.
} 


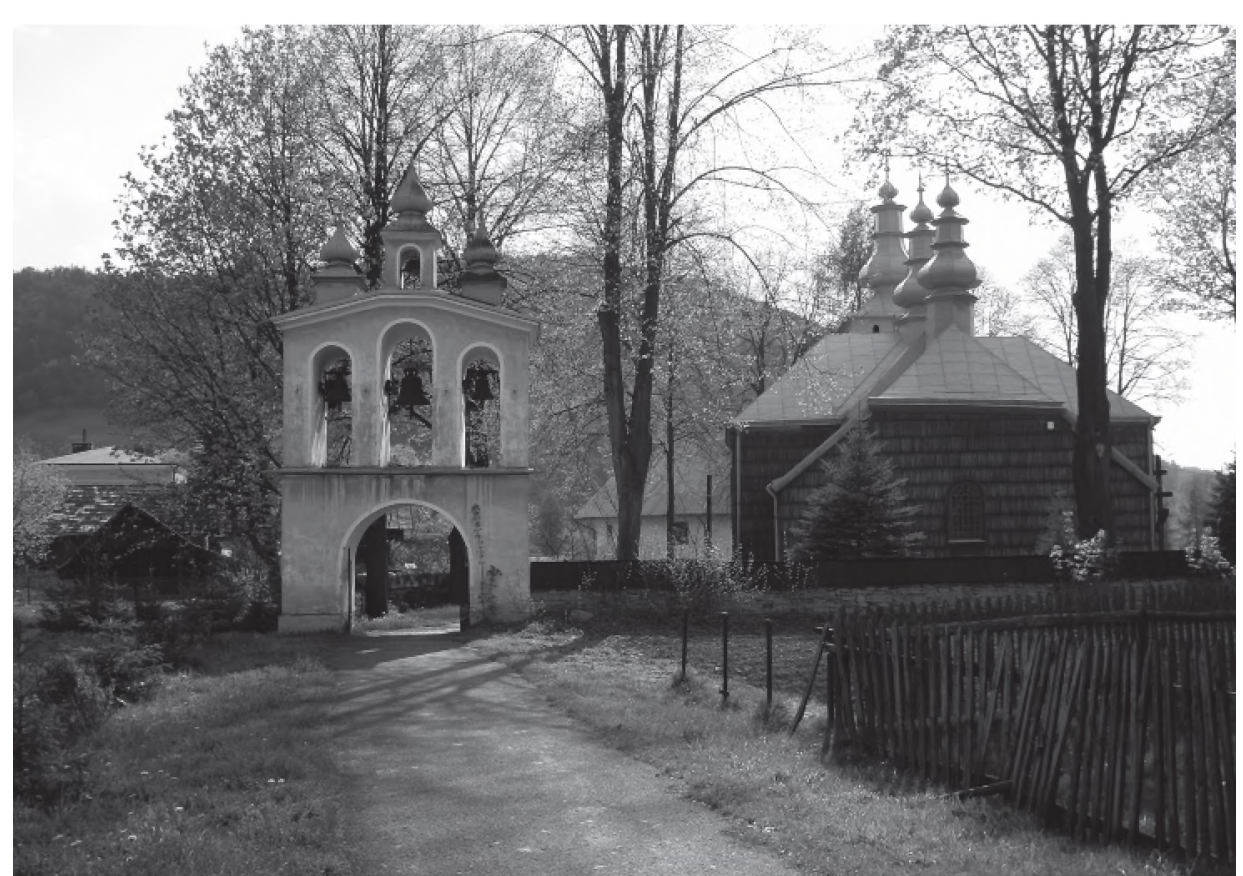

Fot.. 1. Dzwonnica i cerkiew greckokatolicka w Losiu.

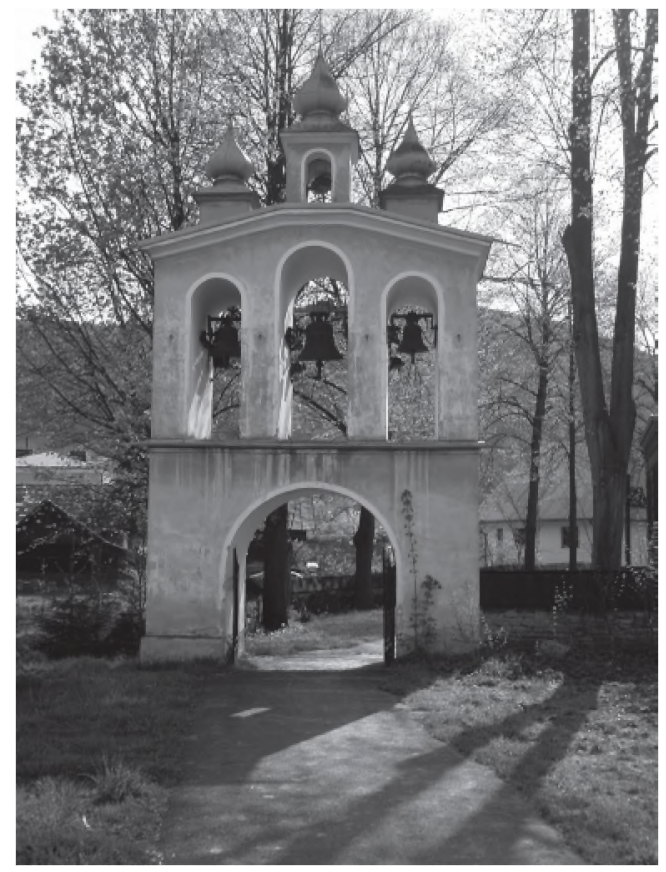

Fot. 2. Dzwonnica przy cerkwi w Eosiu. Fot. Wolfgang Huber. 
Analiza stylistyczno-porównawcza karpackich obiektów sakralnych...

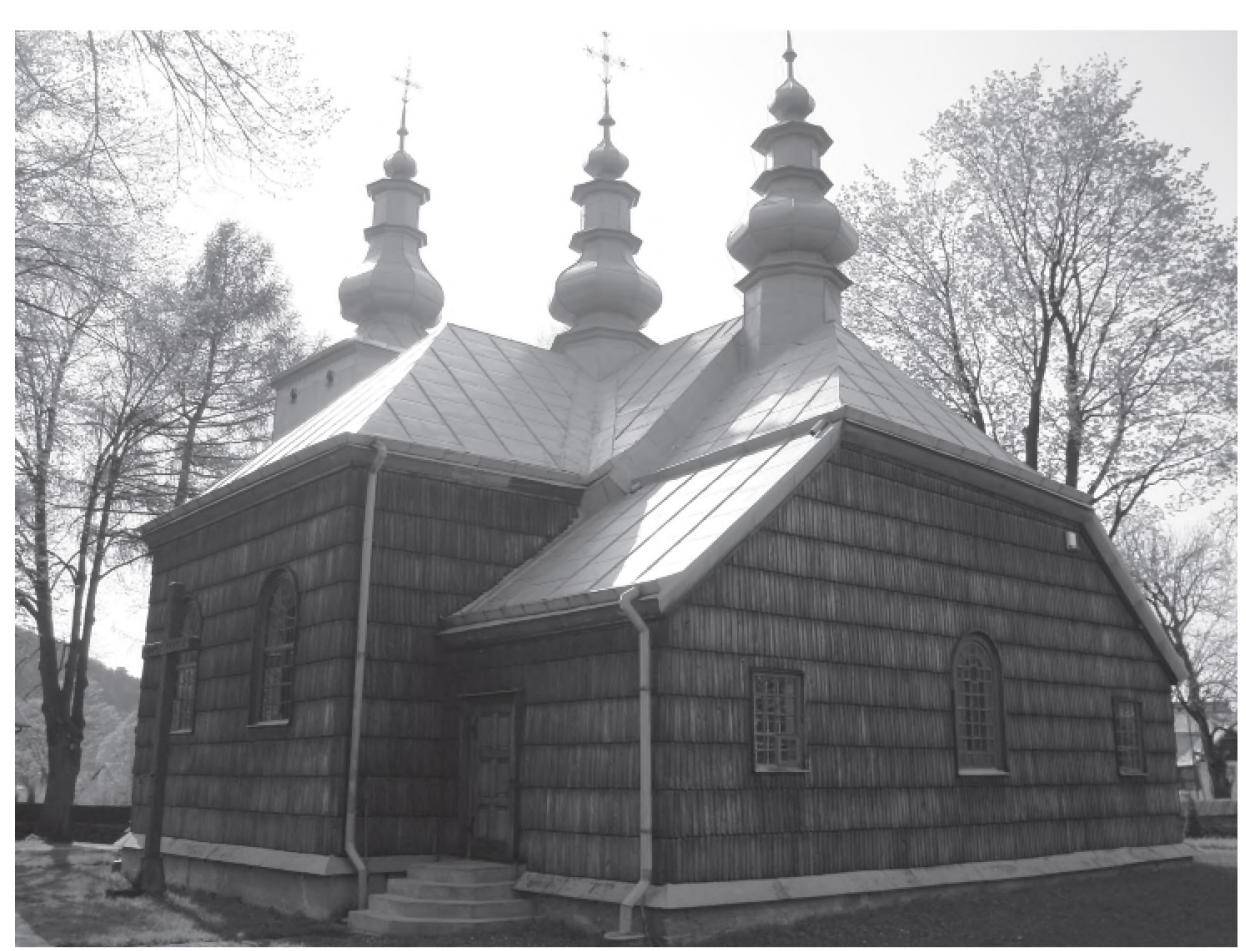

Fot. 3. Bramka wejściowa na cmentarz przy cerkwi w Łosiu.

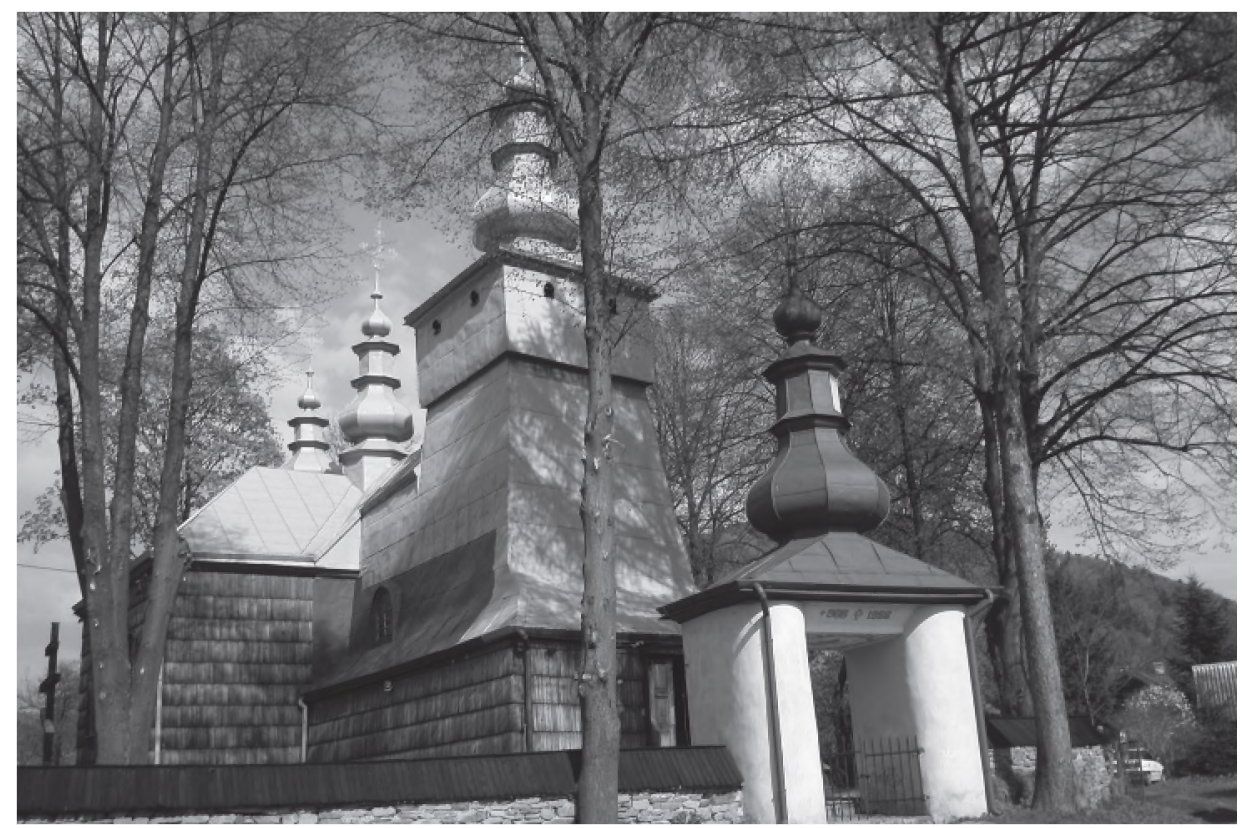

Fot. 4. Cerkiew w Eosiu. Fot. Wolfgang Huber 


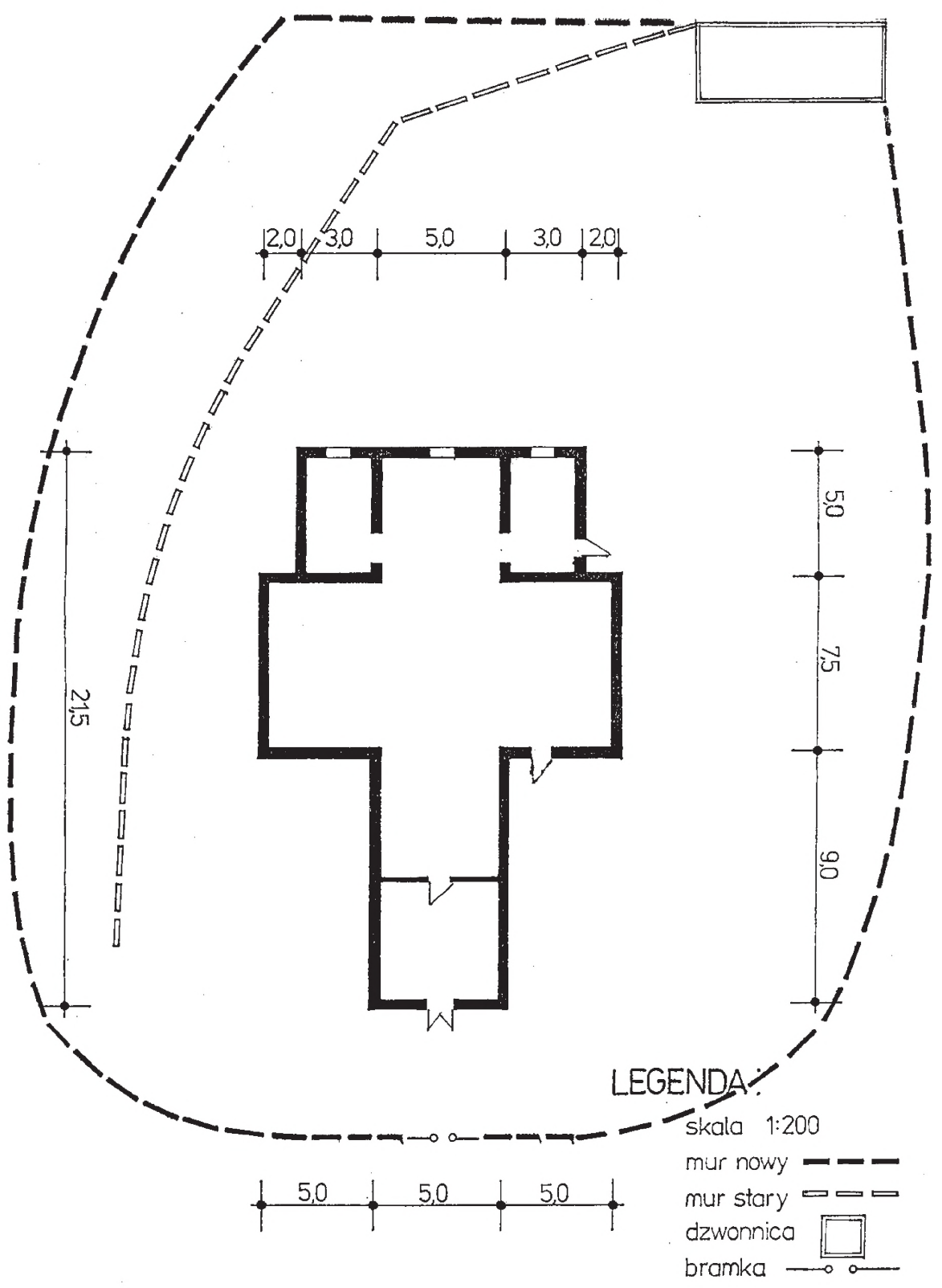

Rys. 1. Plan cerkwi w Łosiu. Fot. Wolfgang Huber 